International Journal of Engineering \& Technology, $7(4.34)(2018) 214-216$
International Journal of Engineering \& Technology
SPC
Website: www.sciencepubco.com/index.php/IJET
Research paper

\title{
Analysis of Financial Performance based on Liquidity and Profitability Ratio (Case Study on PT Unilever in period 2013-2017)
}

\author{
Muhammad Ali*, Diah Andari, Bunga Indah Bayunitri, Andry Ariffian, Sugiartiningsih \\ Widyatama University, Bandung, Indonesia \\ *Corresponding author E-mail: muhammad.ali@widyatama.ac.id
}

\begin{abstract}
This research method uses secondary data from PT Unilever's financial statements in the period 2013 to 2017, the final results of which can be used for decision making for management or outside parties that have a need for the company. The purpose of this analysis is carried out namely as a basis for making relevant decisions so that the company or interested parties have a minimum basis for decision making. The results of this analysis indicate that the company is declared to be less liquid when viewed from the results of liquidity ratio analysis based on theory, but stated either when viewed or compared with other leading companies. The results of the profitability ratio analysis are above the industry average and in practice the company is indeed in a stable condition. To compare with theory and results of conclusions based on practice, so that it can be assessed that companies use funds effectively and can be judged that the company is in good condition.
\end{abstract}

Keywords: Liquidity; Profitability.

\section{Introduction}

\subsection{Research Background}

Analysis of Financial Statements certainly has a very important role to process the financial statements of the company, so that from the results of the calculation of the financial statements the company can find out its weaknesses and strengths and know what steps should be taken from the results of the analysis. "Analysis of financial statements is an activity that aims to determine the health condition of the company by analyzing the relationship of the posts contained in the financial statements" [2]. Companies usually analyze financial statements in a certain period using formulas ratios including liquidity ratios and profitability ratios.

Liquidity Ratio is a ratio that shows the level of the company's ability to pay debts - short-term debt owned. If the company is considered to have enough ability to meet its short-term obligations, then the company can be called liquid. According to [3], liquidity ratio is a ratio that describes the company's ability to meet short-term (debt) obligations. We recommend that if the company is unable to meet its short-term obligations, the company is said to be liquid. In addition to the liquidity ratio, financial ratios can also be measured using ratios.

Profitability Ratios are used to measure financial statements that can describe a company's ability to generate profits over a certain period of time, Profitability is the relationship between revenues and costs generated by using the firm's assets- both current and fixed-in productive activities. By using this profitability ratio, creditors can assess the development of companies that will be given credit in the future.

Based on the description above, it is explained that the Liquidity and Profitability Ratios are very important for internal and exter- nal parties of the company and to measure the company's ability to fulfill its obligations in obtaining profits, the authors want to know about the performance of PT Unilever using liquidity ratio analysis and profitability ratio.

\subsection{Problem Identification}

From the above formula, the problems that will be taken in this scientific research are as follows:

1. What is the liquidity ratio at PT UNILEVER, TBK for 20132017 ?

2. What is the profitability ratio at PT UNILEVER, TBK for 2013-2017?

\section{Theoretical Basis}

\subsection{Financial Ratios}

Ratio analysis is an analysis method to determine the relationship of certain items in the balance sheet or income statement individually or a combination of the two reports. Financial ratio analysis is a general form or method used in the analysis of financial statements. Ratio analysis is useful for internal analysts to help management make evaluations of the results of its operations, correct errors and avoid situations that can cause financial difficulties. Financial ratio analysis according to [4] is: "Future oriented or future oriented, meaning that with financial ratio analysis can be used as a tool to predict financial conditions and future results of operations". With historical ratio figures or if possible with industry ratio numbers (which are supplemented with other data) can be used as a basis for the preparation of projected financial statements which is one form of corporate financial planning. 
"The financial ratio is a number obtained from the comparison of one financial statement account with another account that has a relevant and significant relationship".

Definition of financial ratio analysis according to [1], "This financial ratio or financial ratio is very important for analyzing the company's financial condition. Short and medium term investors are generally more attracted to short-term financial conditions and the company's ability to pay adequate dividends. This information can be known in a simpler way, namely by calculating the ratio of financial ratios in accordance with the wishes".

\subsection{Liquidity Ratios}

According to [2] states that "liquidity ratio is a ratio that describes a company's ability to meet short-term (debt) obligations". This means that if the company is billed, the company will be able to fulfill the debt, especially the debt that is due. In other words, the liquidity ratio functions to show or measure the company's ability to fulfill its obligations that are due, both liabilities to outside parties (business entity liquidity) and within the company (company liquidity). Thus, it can be said that the usefulness of this ratio is to determine the company's ability to finance and fulfill obligations (debt) when billed.

The types of liquidity ratios that can be used by companies to measure their capabilities are:

- Current Ratio

- Cash Ratio

- Quick Ratio or Acid Test Ratio

The ideal value of the three analyzes should be around $150 \%$ to reflect that the condition of the company is in good condition.

Table 1: Types of liquidity ratios [3]

\begin{tabular}{|c|c|c|}
\hline \multicolumn{3}{|c|}{ Table 1: Types of liquidity ratios [3] } \\
\hline No. & Item & Industrial Standard \\
\hline 1 & Current Ratio & $200 \%$ \\
\hline 2 & Quick Ratio & $150 \%$ \\
\hline 3 & Cash Ratio & $50 \%$ \\
\hline
\end{tabular}

\subsection{Profitability Ratios}

Profitability is a net result of a number of company policies and decisions. Profitability ratios measure how much the company's ability to generate profits.

- $\quad$ Profit Margin (Profit Margin on Sales)

- Net Profit Margin

- Net profit margin

- Operating ratio

- Return on Investment

- Return on Equity

- Return on Asset

\section{Results and Discussion}

\subsection{Liquidity Ratio}

\subsubsection{Current Ratio}

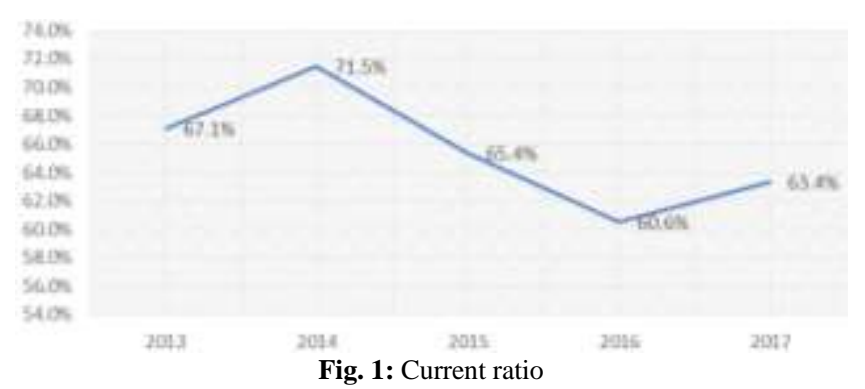

When the value of Current Ratio reaches $100 \%$ or equivalent to the value of one, it means that the company has the ability to cover current debt with current assets with the same value. So, the greater the value of Current Ratio reflects the ability of companies that are also getting bigger and able to cover current debt [2]. However if the results of the analysis are too large then the company is not good too, this is because the possibility of the company having assets that are less productive so that it affects income.

From the graph, it can be seen that there is an increase and decrease. There was a significant decline from 2014 to 2016 of $10.9 \%$. This was due to an increase in current debt greater than the current assets.

\subsubsection{Cash Ratio}

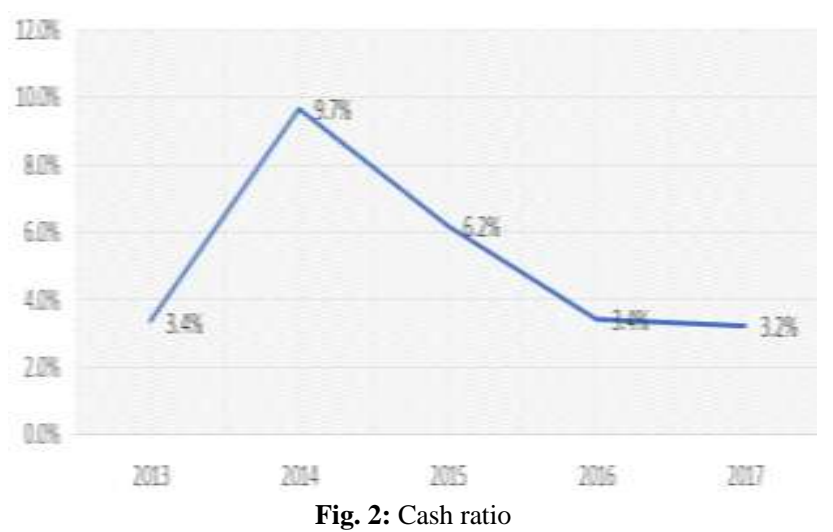

The general industry standard for cash ratios is 50\%. From the graph, it can be seen that there is an increase and decrease. There was a significant decline from 2014 to 2016 of $6.3 \%$. This was due to an increase in current debt greater than its current assets. For the standard cash ratio itself, in fact there is rarely that reaches $50 \%$. This is because if the ratio is high, then the cash that is owned by the company is also high. If cash is too high, then the possibility of cash is less or even unproductive in generating profits. So, most companies prefer to have standard cash or tend to be relatively low, so that it can drive the company's operating capability or investment so that profits become higher and so on.

\subsubsection{Quick Ratio}

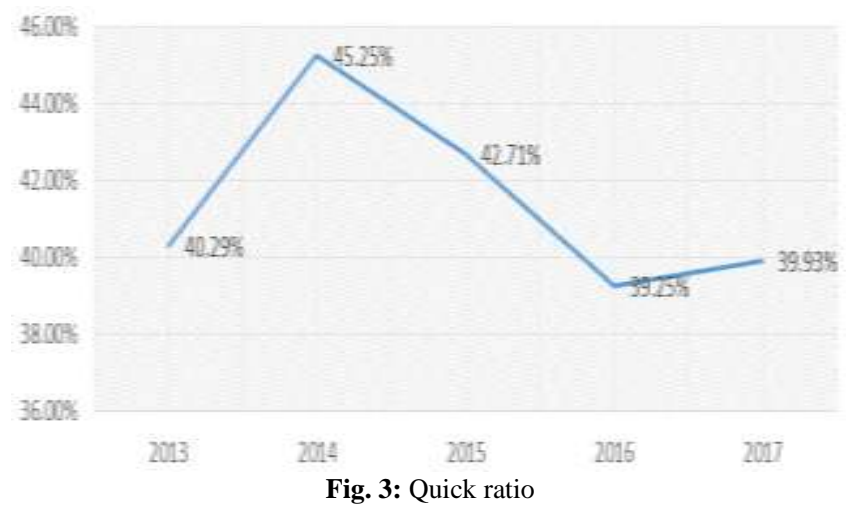

It is better if this ratio can reach 1: 1 or $100 \%$ because if liquidation occurs then the company can pay its short-term liabilities because the source used is fast assets that can be cashed. The ideal value of the three analyzes should be around $150 \%$ to reflect that the condition of the company is in good condition.

The results of the analysis show that the percentage of the quick ratio (quick ratio) is below the industry average standard, which means that companies are less able to pay short-term obligations using more liquid assets. In fact, the company does not always pay the current debt only uses these assets. If the results of the analysis are too high or reach $100 \%$, it is not good because it is worried 
that it will affect its income because the liquidity is too high and there are idle funds, so that the funds are not productive.

\subsection{Profitability Ratio}

\subsubsection{Gross Profit Margin}

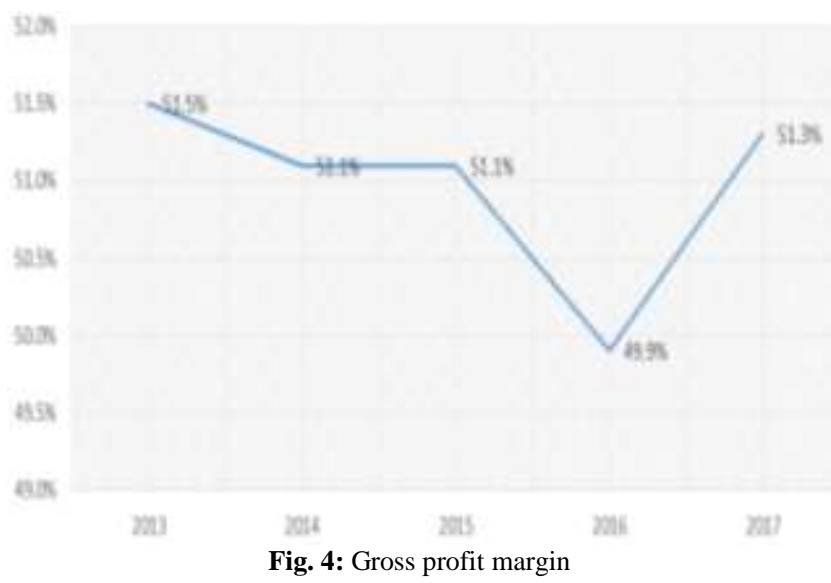

From the graph, it can be seen that there is an increase and decrease. There was a decrease from 2013 to 2016. This was due to the increase in sales from that year was lower than the increase in sales then in 2017. There was an increase from the previous year because the portion of increased sales affected the cost of goods and then the cost of goods also increased. The general standard of the industry average for profit margin is $30 \%$, if it is above the average then the profit margin of a company is good [3]. In fact, the results of this analysis are appropriate and show the company is stable.

\subsubsection{Net Profit Margin}

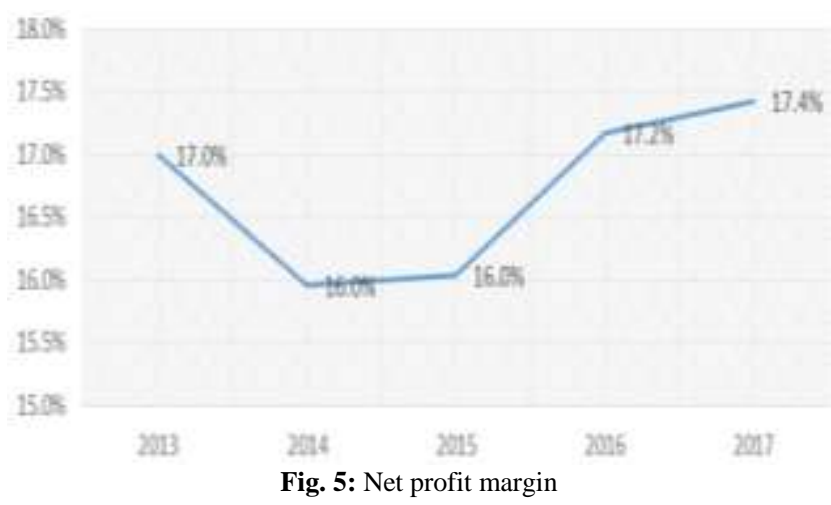

From the graph, it can be seen that there is an increase and decrease. There was a significant decline from 2013 to 2015 and increased in 2016 and then declined again. This is due to the increase in costs and high taxes, as can be seen in the gross profit margin section. The ratio that is generated is still in the range of $49 \%$ to $50 \%$, which is still far from the industry average. Industry Standard for this Ratio is $20 \%$ [2]. In fact, the results of this analysis are appropriate and show the company is stable.

\subsubsection{Return on Assets}

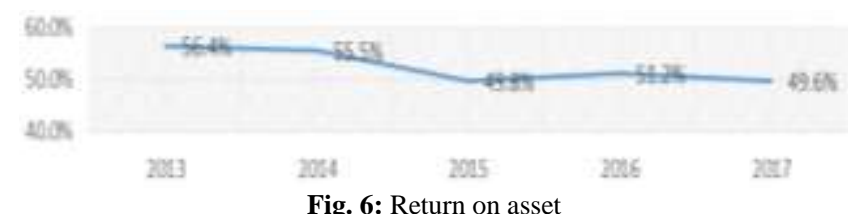

Based on the graph above, there is a significant decrease without a high increase, this is because the increase in profit after tax is higher than the increase in assets every year. The total decrease in
Net Profit Margin was 2.5\% with a 1.4\% increase in 2015 to 2016. In fact, the results of this analysis were appropriate and showed the company was stable.

\subsubsection{Return on Equity}

From the graph above, we can know that there was a decrease from 2013 to 2015. This is because the increase in profit after tax and interest is lower compared to the increase in equity. In 2015 to 2017, there was an increase which indicates an increase in Equity greater than the increase in Profit after Tax and Interest. In fact, the results of this analysis are appropriate and show the company is stable.

\subsubsection{Return on Investment}

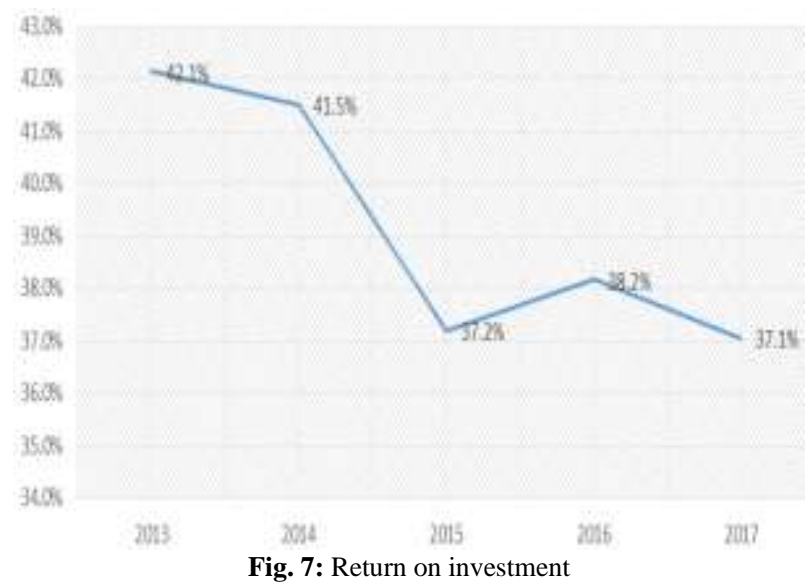

This industry standard ratio according to [3] is $30 \%$ where the higher this ratio, the better the company's performance, especially in returning the investment it gets.

From the graph, it can be seen that there is an increase and decrease, this graph shows that the comparison of the company's profit from year to year decreases. This is due to a decrease in profit margins due to low asset turnover.

\section{Conclusion}

Based on above analyze results of the study, the authors conclude the results of the calculation of the ratio that has been explained in the previous chapter as follows:

The results of this analysis indicate that the company is effective in using its funds so that it is less likely that the company has idle funds. Companies generally do not rely on one component to fulfill their obligations, so that it can be concluded that the company is in a stable condition.

The results of this analysis have to do with the results of the analysis of liquidity ratios where funds owned by the company are managed effectively, so that the company generates high profits even the results of this analysis indicate that it is above the existing industry standards. It can be concluded that the company is in a stable condition in generating profits, both from operating activities and investment activities.

\section{References}

[1] Fahmi, I. (2012). Analisis laporan keuangan. Alfabeta.

[2] Kasmir. (2014). Analisis laporan keuangan. Rajawali Pers.

[3] Kasmir. (2008). Analisis laporan keuangan. Raja Grafindo Persada.

[4] Munawir. (2010). Analisis laporan keuangan. Liberty. 